\title{
STRUCTURAL FLEXIBILITY AND CORPORATE RESPONSIVENESS IN THE BUSINESS ENVIRONMENT: A THEORETICAL REVIEW
}

\author{
Georgewill, Ibiba Ambie ${ }^{i}$ \\ Department of Management, \\ Faculty of Management Sciences, \\ Rivers State University, \\ Nkpolu-Oroworukwo, PMB 5080, \\ Port Harcourt, Nigeria
}

\begin{abstract}
:
The diverse nature of modern business operations and environment has made it a strategic necessity for organization to have a proper understanding of the spontaneous activities in their business environment. It was based on this notion that this study theoretically reviewed literature on the role of structural flexibility on corporate responsiveness to business environment, $\mathrm{x}$-rayed the three basic measures of corporate responsiveness. Consequently, the study found that structural flexibility plays inestimable role in the facilitating of corporate responsiveness in reacting to changes in business environment. Given these findings, we conclude that in the organization, structural flexibility predicts corporate responsiveness. Finally, the study recommended thus: that management of organization should emphasize the need for the effective reconfiguration of its system to ensure the development of capabilities that fosters flexibility and seamless operations and that organizations should provide the necessary leadership that will motivate employees to develop and sustain skills that facilitates responsive actions.
\end{abstract}

JEL: D01; D20; D23

Keywords: structural flexibility, corporate responsiveness, business environment, adherence, promptness

\section{Introduction}

Every organizations carry out its business activities in a specific business environment, the environment in which these organizations operate is known to have a grip of influence on their operations. It is an obvious fact, that many firms conduct their business in environment whereby they are expected to meet expectations and needs of its diverse

i Correspondence: email ibiba.georgewill@gmail.com 
publics, hence the need to formulate strategies that would help them not only meet their need but surpass the expectations in a bid to accomplish goals. Organizations operates within an environment with high competition which influence the firm's strategic process and hence determines the firm's achievement and purpose, therefore the survival and success of an organization can be accomplished if the firm has the resource faculty to design and bring into line strategies that is capable of helping it muddle through perceived environmental Challenges (Umelue \& Akwaeze, 2019). This is usually influenced by both the internal environment and the external environment. In our intervening time, we have experienced spontaneity with regards to technological alteration, uncomplicated entry by foreign multinational corporations and the quickening breaks down of traditional industry borders, this has subjected domestic firms to new impulsive competitive pressures. It is worthy to emphasize that in today's business ambience, it is widely known that present-day organizations that are operating in a vigorous market context, most often have to develop capacities to deal with these exigencies by initiating and executing strategies that permit quick reconfiguration and redeployment of assets in its bid to muddle through these environmental changes without losing its form. But it appeared that the environmental forces pose serious challenges to some Organizations without matching organizational response and as such this seems to threaten the possibility of this organization to objectify their respective defined goals (Ozioko, 2017).

The recent outbreak of the covid-19 pandemic has also brought a new twist in the environmental challenges confronting business organization across the globe. The devastating effects of this pandemic on the economies nations and distortions on the operations of organization is quite threatening and have resonated the interest of both scholars and professionals for managers of organizations to develop apposite strategies to enable the swiftly respond to the ever changing expectations of customer and that of its competitors in their bid to remain competitive. Responsiveness is the attainment of quality of service, this plays pivotal role in surpassing customer's expectation, it is the willingness and preparedness of organizations to offer service by taking into consideration timeliness of services (Kumar \& Charles, 2010). Responsiveness in this regard is that act of being ready and disposed to offer services in a timely manner to clients in a bid to meet or surpass their expectation by utilizing information obtained from the market, responsiveness is important in creating a good impression in the minds of customers which will likely increase their tendency in prolonging their relationship with the organization. Through technology, organizations are now able to perform unswervingly and respond swiftly in line with customers' obligation that will bring up the level of customers' satisfaction (Shariq \& Tondon, 2012). In other words, while sensing capability generates knowledge of the business environment, responsive capability mobilizes and transforms resources to react to the opportunities that it senses. Goromonzi (2016), opine that the effective implementation of strategy, by organization and their ability to develop strategic partnership has shown that the strategy implementation of an organization had a positive association with its performance. One 
of the strategies that organizations adopt during situations of intense changes in their business environment and competition is structural flexibility. There has been a plethora of definition of structural flexibility by numerous scholars, Zakon described it as the feature and the competence of any organization to stay irrepressible while responding freely to recent and fluctuating stimuluses, by transforming and participating in valuable activities (McDowell, 2013). Having a flexible structure is important in today's organization because it enables organization to become very proactive in facing unforeseen and unexpected challenges in operations and creates a valuable opportunity for attainment of competitive advantage. Structural flexibility is an organization's adaptive maneuvering capacity (Ozioko, 2017). Against this backdrop, this paper examines the relationship between structural flexibility and corporate responsiveness of firms in challenging business environment.

\section{Literature Review}

\subsection{Theoretical Framework}

This study is rooted in the dynamic capability theory which is closely related to the resource-based view of the firm (Barney \& Hesterly, 2010). A firm's comprehension of the systems of actions that lead to effective strategic orientations in dynamic markets is imperative, because it could enhance firm's understanding of diverse market situations and the extent of competitiveness (Etemad, 2015). Understanding the level of competition springing up in the business environment from the activities of rivals is key in determining the kind of strategies to initiate and implement in a bid to muddle through the treat they may likely pose to an organization, development of dynamic capability as a recourse is essential in building capacity in this light to challenge as well as outcompete rivals. Analysis of the behavioral aspects of the strategic orientations of firms' units operating in different markets has accordingly received increasing attention (Cadogan, Boso, Story, \& Adeola., 2016; Pehrsson, 2016; Dong, Hinsch, Zou, \& Fu, 2013, Gnizy, Baker, \& Grinstein, 2014). This is vital in helping firms to obtain requisite feedback that will be very useful in crafting action plans to react in response to the altering expectations of clients in one hand, the situations in the market environment and activities of close competitors.

The dynamic capability view is an extension of this and has been developed in order to understand resource configurations when there is market dynamism. Dynamic capability can be viewed as the capacity to sense, shape, and seize environmental threats and opportunities, and maintain competitiveness based on tangible and intangible resource acquisition. A dynamic capability, therefore, helps in reconfiguring a firm's resources and procedures in fluctuating environments (Wan, Hoskisson, Short, \& Yiu, 2011). In the dynamic capability view, the firm and its different units need to develop dynamic capabilities in order to realize competitive advantage and improve performance in dynamic markets (Pehrsson, Ghannad, Pehrsson, Abt, Chen, \& Hammarstig., 2015). The ability to reconfigure structures by making it very flexible and development of 
capacity to respond effectively to changes in the business environment are known examples of such capabilities thus corroborating the earlier views of scholars such as Barreto (2010) and Gnizy et al. (2014). This has compelling implications for resource configurations intended in building competitive advantage. It is important to note that, to seize market opportunities, organizations diverse units may integrate as well as adjust its resource configuration in terms of market knowledge received or accumulate knowledge itself (Pogrebnyakov \& Maitland, 2011).

Structural flexibility and responsiveness are crucial to firm performance because they manifest firms' strategies in markets and are actionable (Dong et al., 2013). Structural flexibility represents a firm's maneuvering capacity and market-driving behavior that facilitate firm's ability to get ahead of competitors by being the first to, initiate, introduce novel products or service in new markets. While this is attainable and vital to organizations competitive drive, responsiveness on the other hand is a market-driven firm behavior; that gives a firm that capacity to customize its products and build lasting customer loyalty and relationships, the firm may respond to the needs of target and prospective customers at the same time. The firm's ability reconfigures its structure and systems and combine resources in new ways is therefore crucial as there is a need for new processes, business models, complementary assets, and methods in order to capitalize on environmental opportunities, in this instance such reconfiguration is important in improving market performance and dominance. Drawing on the dynamic capability view, this study establishes that structural flexibility and responsiveness are strategies that are relevant in extending the understanding of the actionable components of firms' various units that is imperative in enhancing performance.

\section{Conceptual Framework}

The conceptual framework is usually a diagrammatical illustration of the relationship between dependent variable and independent variables in a study. In this paper, corporate responsiveness is classified as dependent variable or better still the criterion variable, while structural flexibility is classed as the independent variables or predictor variable. The conceptual framework for this study made an attempt to elucidate a consolidative view of the role of structural flexibility in predicting corporate responsiveness of firms to changes in its business environment with measures as (Adherence, promptness, market intelligence) Therefore, a conceptual framework is established as shown in Figure 1. 
Figure 1: Conceptual Framework

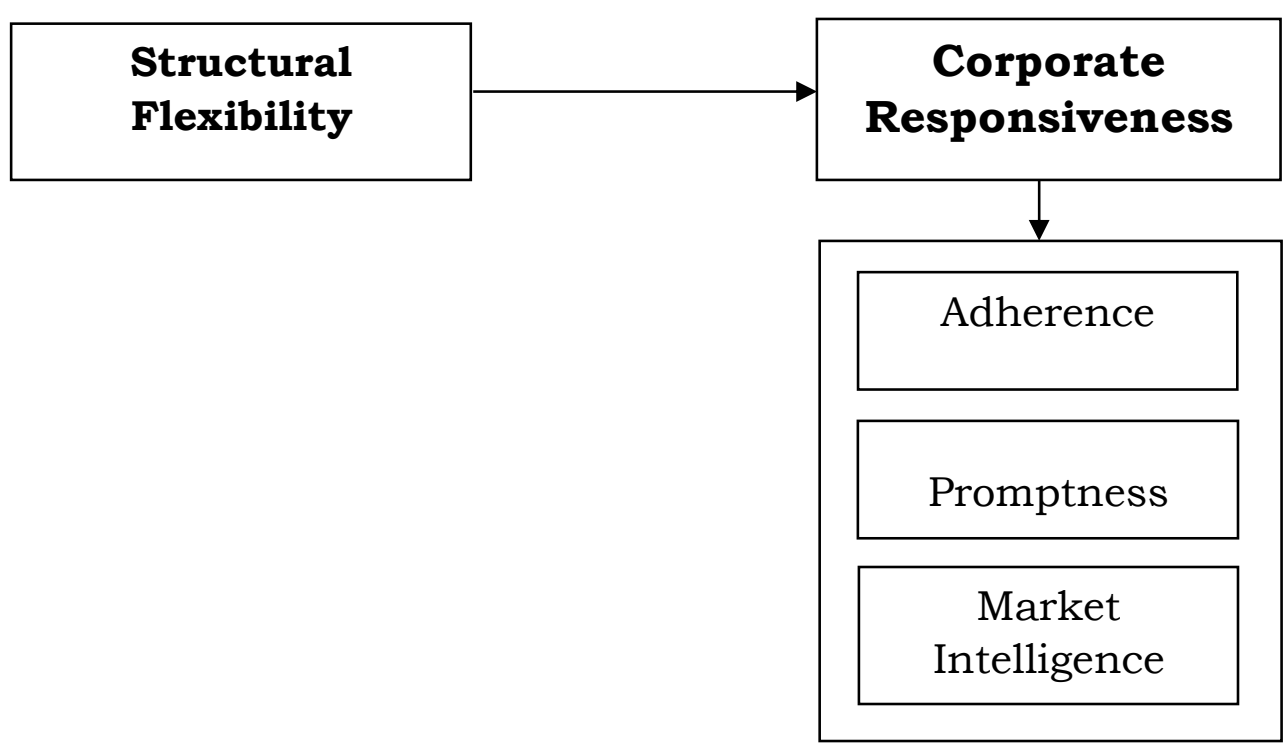

Source: Researcher's Conceptualization from Review of Related Literature, 2020.

\section{The Concept of Structural Flexibility}

Structural flexibility entails the managerial competences or skills developed to evolutionarily adjust the organization strategies to alterations in their business environment. The scope of organizational alterations that is triggered by structural flexibility traverse's organization structure and processes. Structural flexibility is the management's ability to adapt unique ways in which responsibility, authority and working processes are allotted to the organization's members (Hao, Kasper \& Muehlbacher, 2012). The budding of structural flexibility in organization lies on the definite distribution of responsibilities and authorities in relation with basic organizational structure, and the planning as well as the control systems and the process regulations of decision-making, coordination, and implementation. In today's business climate, it has become imperative that for organizations to cope with market unpredictability and vagueness, firms need flexible organizational boundaries such as networks, joint ventures and flat structures with basic elements of hierarchy that accommodate efficient managerial processing of information. Angeles, Centeno and Villanueva (2019), espoused structural flexibility with factors such as organisational design, formalization, communication, management team, and decision-making. Organisational design refers to the firm's horizontal or vertical structure. To achieve structural flexibility, there must be greater level of horizontal configuration, this is because flatter structures allow for more open and direct communication and information flows better for timely decision-making (Bamel, Rangnekar, Rastogi, \& Kumar, 2013). Formalisation echoes the importance of regulations in the maximization of control of operational activities and the ability to minimize deviations. Communication involves the exchange of organisational knowledge of different areas, it helps to identify problems and apply solutions (Bamel et al., 2013). The difficulty in consolidating 
communication is that, even though it aids in taking healthy decisions, it poses delay problems which are critical in dynamic environments. In respect of the management team, firms that adopts structural flexibility often have a diverse group of people with distinct backgrounds. The heterogeneous firm has intellectual miscellany which helps to take risks and enhancement of action ability, while the standardized organisation discloses perceptive restrictions that limits management's action capacity.

Structural flexibility is seen in another way as organization's adeptness to adjust its management in such a way that roles and functions, authority and working course of action are allocated to the organization's workforce (Hao et al., 2012). In this instance, decision making is altered in such a way that create room for the contribution and use of valuable information from all employees and team members, this enhances bottom up communication and diminishes top bottom information flow.

Organisational decision-making controls the accessibility of resources in the firm and it is necessary to boost the superior access to future opportunities (Kandemir \& Acur, 2012). Decision-making processes can become unbending if the organization do not have clear objectives or there are frequent conflicts among employees, or the firm is facing business downturn as a result of decline of profits (Carrasco, Angeles \& MarroquinTovar, 2016). Importantly, while research has developed theoretical decision-making models suited for large companies, these models present application problems (Baltar \& Gentile, 2012). In small organizations, owner-managers are responsible for the decisionmaking procedure and the execution of entrepreneurial, operational and leadership strategies, they are pressured to be experts in all management fields. In contrast, in large organisations these responsibilities might be split across different professional managers who are only accountable for the decision-making process of their area (Teece, 2016). In this sense, aligning all the organization's decisions under one person can increase coordination problems and reduce the organisational flexibility. In summary, organisations with greater structural flexibility tend to have a more heterogeneous management team where decision-making is decentralized; they have few hierarchical levels and formalization, and more open and direct communication channels. Also, firms with less structural flexibility show steeper hierarchies, stricter regulations, and centralised communication and authority.

\section{Concept of Responsiveness}

A lot of positive acknowledgement has been adduced to the fact that in times of unrestrained challenges and competition that developing the capacity to act in response to changes by any organization is a critical success factor for such organization. But, the reality of the intervening turbulent organizational environments is that most organizations have to muddle through all of them instantaneously and to avoid a repeat in the future, and as such they should develop the capacity to effectively coalesce repetitive behavior with creativeness competences. Several organizations in developing economies; Nigeria not excluded, both in the past and present are dealing with 
multifarious challenges that have been making them to look less competitive at home because of the increasing influx of imported foreign products that is flooding the domestic market. This, coupled with challenges of non-availability of basic infrastructures such as electricity, good roads, technology and funds that should have been pivotal in boosting the productive capacity to serve these markets before dreaming of expanding internationally, and with the scourge of the Covid-19 pandemic, the future looks very bleak for their survival and vitality

Responsiveness is the attainment of quality of service, this plays pivotal role in surpassing customer's expectation, it is the willingness and preparedness of employees to offer service by taking into consideration timeliness of services (Kumar \& Charles, 2010). Responsiveness in this regard is that act of being ready and disposed to offer services in a timely manner to clients in a bid to meet or surpass their expectation by utilizing information obtained from the market. It is facilitated by a comprehension of customer's safety needs, social status, psychological disposition and individual attention given by employee as well as convenient operating hours. These are vital in satisfying customer's expectation; thus, responsiveness is important in creating a good impression in the minds of customers which will likely increase their tendency in prolonging their relationship with the organization.

Responsiveness to customer expectations is a crucial competitive factor in the current business environment of today's universal and volatile marketplace, with increasing product varieties, spontaneity in customers tastes and preferences, shortening life cycles and more demanding competition (Danese, Romano \& Formentini 2013). The ability to consistently, offer the right product or services to its array of loyal and prospective clients at the right time at the right place and at the required quality is the main objective of any organization. In order to become more responsive, organization needs to be swifter and stretcher in their operations. However, in their bid to accomplish the objectives of developing desired competitive capabilities, many firms increase their investments in acquiring advanced operational technology to deepen its operational effectiveness and efficiency. Farooq and O'Brien (2015), state that firms, when making decisions regarding technology selection, should consider direct and indirect consequences on all partners in their value chain. Kim, Cavusgil, and Cavusgil (2013), had espoused that, in the present hypercompetitive market, a firm's individual capabilities and efforts, by themselves, are not sufficient, but rather the firm must rely on its supply chain partners to create responsiveness to customers and generate added value for them.

A firm's capacity to comprehend and utilize the requisite procedures necessary to roll out actions that will grow quickly into an effective strategic orientations in dynamic business environment has become very vital, this is because it will assist in improving firm's sensitivity to different market situations and the influx of internationally influenced competition in its domestic markets (Etemad, 2015). A critical scrutiny into the behavioral outlooks for engendering the strategic orientations of firms' operation in any market has subsequently been acknowledged with increasing consideration from 
numerous scholars and professionals (Cadogan et al., 2016; Pehrsson 2016; Gnizy et al., 2014; Dong et al., 2013). Thinking, in line with the above expressions offered by scholars, it has become very imperative that corporate responsiveness to unexpected occurrence of events in the business environment in which organizations operate is instrumental to the attainment of requisite competitive advantage that will help them maneuver competitive incursions from close competitors. Responsiveness is clearly, an organizations tendency to utilize market information that is engendered and effectively disseminated in adding value to the operations and success of organizations. Corporate responsiveness thus has both strategic and operational process such as organizational sensing and modular organizing. Sensing is best described as an organization's capability to think through its complex relationship with the outside world, while the modulating process entails three distinct stages of perceiving, construing, and acting. Corporate responsiveness depends on the cumulative sensing effort of all organizational members. The theme of corporate responsiveness requires that organizations develop flexibility to act in response with dexterity to premeditated and operational necessitates simultaneously, but unfortunately this has been under-explored in strategic management studies, except in recent times. To explore corporate responsiveness, this study draws upon the response experiences of organizations across the globe. It uses the expeditionary crisis-response task setting of many of today's global organizations as a metaphor for organizations confronted with environmental turbulence such as the covid-19 pandemic that have and is still taking a toll in the global economy (Butler \& Riveria, 2020). In line with the views of this scholars, its obvious that the outbreak of the Covid-19 pandemic has revolutionized the way organization views competitions and responses to changes in the business landscape.

Given that, responsiveness is a market-driven behavior of the firm, it requires some kind of market maturity, as customers, competitors, and other relevant market actors need to be distinguished from one another. In corroborating previous works of scholars, Pehrsson (2014) advocated that organizations as key players should be able to postulate an appropriate level of responsive actions towards accomplishing customer needs, such as product customization and building customer relationships. Creating effective responsiveness therefore means that the firm tries to achieve responsiveness based on wide-ranging knowledge of its customers and competitors; this necessitates a well-designed system for engendering and circulating market information. This paper, however, progresses by reviewing literatures on three (3) measures of corporate responsiveness namely, adherence, promptness and market intelligence.

\section{Adherence}

Ensuring employee adherence to work-place rules and procedures is one important foundation of successful coordination and effectiveness of organizations. It is imperative that organizations develop mechanisms that enable it to stimulate essentially rule adhering behavior amongst their employees, this equally facilitates the ability of the 
organization to adhere to the terms of business agreement with external customers. Rule adhering behaviour is linked to ethical judgments and the fundamental factor known to be shaping them is the procedural justice that employees encounter in their workplace. Adherence is seen as the ability to austerely put into practice all standards and policies in an organization (AlKalbani, Deng, \& Kam, 2014). The adoption and practice of adherence ensures that organizational mechanisms can work together effectively to protect the critical policies and procedures in organization (Ifinedo, 2013). It satisfies the stakeholder's requirements, thus boosting stakeholders' buoyancy and trust in organizations.

Although some studies have documented strong consumer demand for ethically produced goods a recent comprehensive reflection of the literature on market consumerism concluded that the ethical consumer is a myth (Devinney, Auger, \& Eckhardt, 2010). Given this, it could be contended that more general terms that the attitudes and attributes of clients in most home market may sway an organization and its management towards adhering to laid down business practices, these actions reflect the potential for meeting expectations. Most organizations, therefore, often accede to the demands of consumers to adopt adherence capabilities, such as codes of conduct (Fransen, 2012). The goal of any organization is to have employees that behave in a manner consistent with the company's mission and goals that is to say, aligning absolutely with the core values, adhering to the code of ethics and matching actions with beliefs across a variety of plans to meet expectations of satisfying customers need (Pattison \& Edgar, 2011). Securing employee adherence to work-place rules and company policies is one key antecedent of successful coordination and functioning within organizations. It is important for companies to be able to motivate effectively rule following behavior among employees. Shariff, Omar, Sulong, Majid, \& Ideris. (2017), opine that adherence to acceptable procedures engenders customer satisfaction and influences the customers decision for a repeat buy. Boo (2017) described satisfaction as the evaluation of an organizations overall service environment. The post-adoption context explains that expectation is a combination of experiences by which actual usage experience influences consumer satisfaction. Expectation towards a service could be formed by various factors, including experience, advertisement communication, reputation, customer background, and the next-purchase psychological state or the purchase environment at the point of purchase (Baiardi et al., 2016).

\section{Promptness}

The ability of organizations to offer prompt service delivery to its teaming clients and the resulting customer satisfaction do not exist in a vacuum. Since the provision of a service most often include a face-to-face contact between the customer and the service provider, it is imperative that the frontline employees have to be timely, poses requisite tools, the training, the support, and the backing and encouragement not only to satisfy the customer then but to do it in a way that makes the customer come back again and again, 
thus, stimulating customer loyalty. Promptness in service delivery is a kind of personal selling, and encompasses direct interactions between salespeople and potential buyers in one hand and response to feedback from customers on the other hand on their experience during the service encounter (Ozioko, 2017). Poor frontline performance has huge adverse impact on customer satisfaction and probably nothing can assuage a customer who has been treated dismally by a frontier staff. The work systems, policies, and procedures of the organization should empower the caliber of staff to do whatever is possible to please the customer; hence, top-management vision is important. Promptness according to (Ozioko, 2017), is necessary in attaining competitive advantage because the timely meeting of the need of customers leads to increased customer loyalty, satisfaction, and retention. It could also be viewed as an approach that if adequately implemented, will have the tendency to increase the cost of customers switching to close competitors.

Additionally, the primary purpose of strategic management system enhancement has been to improve efficiency in organization and strengthen strategic response capacity, as well as its capacity to attain and sustain competitiveness. Promptness is an organization's demonstrated capacity to react to changes in the environment in record times. This has to do with the firm's ability to choose appropriate strategic objective, formulate and implement strategies effectively, achieve its objectives and develop its resources in accordance with the changing environmental demands. The organizational responses which can hypothetically influence the outcome of satisfaction and repurchase intention is promptness, to this effect, it has been acknowledged that intra-organizational and inter-organizational alliance has become a necessity for excellently dealing with the complexity of business response situations (de Waard, Volberda, \& Soeters, 2012). Prompt service delivery is a kind of personal selling and encompasses direct interactions between salespeople and potential buyers in one hand and response to feedback from customers on the other hand.

Consumers like to commit to business relationship with specific firms because they like the services provided and are assured of certain service privileges. Promptness in service delivery is most often regarded as quality of services by clients and is seen to have positive influence on satisfaction of its customers and it directly contributes to profitability of the organization. Good quality of service provides numerous benefits to organization like better brand image, enhancement in customer satisfaction, cross selling opportunities, decreased customer's negative turnover, amplified likelihoods of word to mouth recommendation and facilitates the maintenance of long term and good customer relationships. Promptness is seen as one of the numerous indispensable skills for success in the workplace and, further very important for ensuing success in the individual's career prospect. An employee who makes available required material to facilitate prompt production efforts, or who swiftly informs his or her managers to an uninvited situation, or who briskly carries out and completes a multifaceted duty is considered a valued individual and very important to the organization that he or she works for. Several studies have emphasized the importance of the promptness of organizational response 
to customer complaints as a mechanism to generate successful service recovery, thereby increasing customer satisfaction and repeat-purchase intentions (Sparks \& Weber, 2012). The service personnel are pivotal to all kinds of affection from consumers by boosting business relationship and experience (Dunne, Lusch, \& Carver, 2010). Since delivery and customer relationship personnel are the force that directly interrelates with both existing and prospective clients, they are deemed to be the most effective touch points for retail organizations. Prompt employee behavior replicates the ability to develop quick delivery skills and an effective means of handling customer criticisms, which eventually in loyalty and satisfaction and that, in the long run, metamorphoses to a good organizational reputation (Das, Dash, Sahoo \& Mishra, 2018).

\section{Market Intelligence}

Most organizations may not be restricted only to the internal modifications that ensues, though it is important that they must also look beyond their existing corporal structure by embracing a forward-looking concept to enhance their potentials of operating in many diverse economies that will bring to the fore new challenges. The gathering of information, bearing in mind this up-to-date circumstance is well-thought-out as an essential strategic asset that brings about effective decision-making processes (Murphy, 2012). Decision making in the organization can only be seamless and timely when there is enough information to help the decision makers to make better choice. In this perspective, it appears the concepts of market intelligence that involves the procedures of recognition, collecting, administering, examination and exploitation of the information to help attain goals, has become very imperative to organization (Huo, 2014). This has become a new action plan that organization have lately devised as a new means to build required capacities for engendering competitive advantage. Generally, market intelligence has been explained in relation to two connected and important view point thus: as a wide-ranging process of obtaining, disseminating, and deployment of market and customer information to boost a firm's marketing, planning, execution, and control; it could also be viewed as a kind of competitive intelligence targeted at the market and marketing perspective of business thus reinforcing the views of Helm, Krinner \& Schmalfuß, (2014). It comprises of all the activities targeted towards intelligence recognition, gaining, examination, diffusion, and utilization in organizations as can be extricated from information and as it accentuates the translation of information into applicable intelligence and its distribution to end users for decision making.

Rahma (2015), undertook a study on the importance of market intelligence in organizations, the outcome of his study reveals that the marketing information system is an important determinant of market share, therefore, it helps in ascertaining the possible opportunities in the target market. This outcome is uniform with that of Venter \& Resnsburg (2014), studies which substantiates that market intelligence is a set of measures and assets used by marketing managers to collect daily information on recent happenings in the market environment. This corroborates further the findings of Wafy (2013), 
organizations engage in environmental search to recognize their strength, weakness, opportunities, and threats. Ismail (2011), in his earlier study also accepted the outcome of his research and concludes that market intelligence help marketing managers to collect and scrutinize internal and external market information and recent trends in a market. Helo (2013) corroborated this in his own study by stating that the effective utilization of market intelligence system makes available accurate information on current developments in the marketing environment. Furthermore, Khawla (2013), found that gathering of information about the internal and external environment is very essential to all organization.

\section{The Relationship Between Structural Flexibility and Corporate Responsiveness}

According to Faron (2012), structural flexibility has the attributes of a team-based structure. This allows the appointment of employees to participate in certain teams to carry out task(s) and after the completion of these task(s) they go back to their previous units. Here each member of the team gains a greater autonomy and the team leader only plays a supportive and coordinating role rather than control. Some of the structures are organic, dynamic but others are mechanized and static. Each of them has their unity compared to other models (Rabbinz, 2012). Organizational structure can enhance rapid and easy response to alterations, this enables them to adapt in reacting to both internal and external impulse. Responsiveness refers to ability of recognizing changes and quickly taking advantage and benefiting from them. Responsiveness is the ability of a firm to respond to customers' needs in terms of quality, speed and flexibility and it is characterized by combined goals such as time, quality and flexibility (Asree, Zain, \& Razalli, 2010). An organization's performance is often determined by its ability to respond quickly to changes in the business environment.

Responsiveness enables organizations to detect market changes quickly, reconfigure their processes to meet new market requirements, share information across organizational units, take maximum advantage of information processing systems, and adopt new product and process technologies ahead of competitors. While some uncertainty can be handled by planned chance, some can only be handled by being responsive to new challenges and opportunities as they occur. Even though an organization has understood its capabilities, analyzed its opportunities, and set in place strategies to optimize its success in the future, it remains necessary for it to be able to handle unexpected events. In order to achieve this, the organization needs to be adaptable, the potential value of giving attention to a change varies across organizations in terms of relevance, significance, and priority as well as make good decisions as to which changes deserve responses, organizations must be capable of assessing the value of undertaking a response (Ekweozor, \& Obara, 2020). Angeles et al. (2019) employed the utility of a mixed methods approach in the investigation of one of the best-known success factors of small and medium-sized enterprises (SMEs): their structural flexibility (SF), and how this is related to their organisational life cycle (OLC) and found that structural 
flexibility influences organizational life cycle and performance. A reflection on this shows that structural flexibility is a very good capability that organizations should possess to become successful. On the other hand, Ozioko (2017), in his study of organizational agility and corporate responsiveness in the telecommunication sector in Rivers State, by examining the relationship between structural flexibility a dimension of organizational agility and the measures of corporate responsiveness with measures such as adherence, promptness and timeliness and established that structural flexibility has a strong and positive relationship with the measures of corporate responsiveness and by extension corporate responsiveness. Therefore, it can be established that structural flexibility predicts corporate responsiveness.

\section{Linking Structural Flexibility and Adherence}

Structural flexibility entails the creation of teams, which helps in reducing the level of centralization and formalization, hence, creating the room for an increased speed in responding to customers need promptly (Faron, 2012). However, there is no uniformly and accepted definition of structural flexibility of organization, depending on an author's view point, there exists varieties of opinions. Adherence is seen as the ability to austerely put into practice all standards and policies in an organization (Al Kalbani et al., 2014). The adoption and practice of adherence ensures that organizational mechanisms can work together effectively to protect the critical policies and procedures in organization (Ifinedo, 2013). It satisfies the stakeholder's requirements, thus boosting stakeholders' buoyancy and trust in organizations. It is important for companies to be able to motivate effectively rule following behavior among employees. Shariff et al. (2017) opine that adherence to acceptable procedures engenders customer satisfaction and influences the customers decision for a repeat buy. Boo (2017) described satisfaction as the evaluation of an organizations overall service environment. Ozioko (2017), in his study on organizational agility and corporate responsiveness in the telecommunication sector in Rivers State, Nigeria, examined the relationship between structural flexibility and adherence, established that there is a positive and significant relationship between structural flexibility and adherence.

\section{Linking Structural Flexibility and Promptness}

Structural flexibility is the attribute and capacity of an organization to remain resilient while reacting freely to new and altering impulses, changing and winning in valuable activities (McDowell, 2013). More so, structural flexibility enhances the capacity of organization to effectively curb disturbances with alert adaptation without losing its distinctiveness. The authors further stated that, this helps the organizations to resist being overwhelmed by its immediate environmental challenges, rather the organization develop the capability to dominate its environment in other to preserve its identity. To achieve structural flexibility, there must be greater level of horizontal configuration, this 
is because flatter structures allow for more open and direct communication and information flows better for timely decision-making (Bamel et al., 2013). The organizational responses which can hypothetically influence the outcome of satisfaction and repurchase intention is promptness, to this effect, it has been acknowledged that intra-organizational and inter-organizational alliance has become a necessity for excellently dealing with the complexity of business response situations (de Waard, Volberda, \& Soeters, 2012). Prompt service delivery is a kind of personal selling and encompasses direct interactions between salespeople and potential buyers in one hand and response to feedback from customers on the other hand. It is believed that flexible structures lead to the development of firm's capacity to be swift and timely in responding to the expectations of customers and attainment of competitive advantage. Ozioko (2017), in his study on organizational agility and corporate responsiveness in the telecommunication sector in Rivers State, Nigeria, examined the relationship between structural flexibility and promptness, established that there is a positive and significant relationship between structural flexibility and promptness.

\section{Linking Structural flexibility and Market Intelligence}

Structural flexibility offers diverse benefits to organizations in different sectors of an economy, in the manufacturing sector firms develops the ability to fashion effective and dynamic structural flexibility that allows them to have a rapid response to environmental fluctuations unlike those firms in the service sector (Nicholas, Ledwith \& Perks, 2011; Centeno, Hart \& Dinnie, 2013). As the current society is with millions of organizations and institutions, it is required that they are organized in the form of limited configurations. The configurations as suitable for organizing all organizations and institutions are classified in various models and forms.

Structural flexibility is vital in information gathering that is useful in decision making in the organization by making the process seamless and timely, it helps in the collation of enough information to help the decision makers to make better choice. In this perspective, it appears the concepts of market intelligence that involves the procedures of recognition, collecting, administering, examination and exploitation of the information to help attain goals, has become very imperative to organization and could be easily facilitated (Huo, 2014). This has become a new action plan that organization have lately devised as a new means to build required capacities for engendering competitive advantage. However, within the knowledge view of the researcher there has not been an empirically validated study that has established any existing relationship between structural flexibility and market intelligence.

\section{Conclusion and Recommendations}

A deep reflection on the literature examined in relation with the variables considered in this paper, it was discovered that structural flexibility is an unparalleled management 
theme that determines an organizations capacity to effectively act in response to the spontaneous activities in its ever-changing business environment. This is as many scholars have attributed successful attainment of competitive advantage, performance and success of organizations to a progressive acquisition and demonstration of this capabilities in their operations. Also, the three measures of responsiveness namely: adherence, promptness and market intelligence in this paper showed that each of them has something in common with the drive for accomplishment of competitive advantage and customer satisfaction. In the direction of the linking structural flexibility with corporate responsiveness, a strong relationship was observed. This is as structural flexibility was found to be a good predictor of corporate responsiveness which emphasizes the need for reconfiguration of systems within an organization to foster speed which is necessary for attaining corporate responsiveness. And for this to occur, structural flexibility is a necessity. This is why in our intervening time managers and scholars are emphasizing the possession of structural flexibility as a dynamic capability necessary for optimized performance. Finally, the study recommends as follows: that management of organization should emphasize the need for the effective reconfiguration of its system to ensure the development of capabilities that fosters flexibility and seamless operations and that organizations should provide the necessary leadership that will motivate employees to develop and sustain skills that facilitates responsive actions.

\section{Conflict of Interest}

The author declares that there is no conflict of interest.

\section{About the Author}

Georgewill, Ibiba Ambie is a Doctoral Candidate of Human Resource Management in the Department of Management, Faculty of Management Sciences, Rivers State University, Port Harcourt, Rivers State, Nigeria.

\section{References}

Al Kalbani, A., Deng, H., \& Kam, B. (2014). A Conceptual Framework for Information Security in Public Organizations. E-Government Development, 14:56-72

Angeles, A., Centeno, E., \& Villanueva, C. E. (2019). Examining Structural Flexibility Factors in SMEs: A Mixed Methods Study in Mexico, The Electronic Journal of Business Research Methods, 17(1), 28-42.

Baiardi, D., Puglisi, R., \& Scabrosetti, S. (2016). Individual attitudes on food quality and safety: Empirical evidence on EU countries, Food Quality and Preference, 49: 70-74.

Baltar, F. \& Gentile, N. (2012). Mixed methods for the study of strategic decisions in SMEs]. In IBFR, Global Conference on Business and Finance. Honolulu, Hawaii, 3-6 January 2012. Hawaii: The Institute for Business \& Finance Research. 
Bamel, U., Rangnekar, S., Rastogi, R. \& Kumar, S. (2013). Organizational process as antecedent of managerial flexibility, Global Journal of Flexible Systems Management, 14(1),3-15.

Barney, J., \& Hesterly, W. (2010). Strategic management and competitive advantage: Concepts and cases. (3rd ed.). Massachusetts: Prentice Hall.

Barreto, I. (2010). Dynamic capabilities: a review of past research and agenda for future research, Journal of Management, 36(1), 256-280.

Boo, H. V. (2017), Service environment of restaurants: Findings from the youth customers. Journal of ASIAN Behavioural Studies, 2(2), 67-78.

Butler, M., \& Rivera, K. (2020). Seven key actions business can take to mitigate the effects of COVID-19. UK: PWC.

Cadogan, J. W., Boso, N., Story, V. M., \& Adeola, O. (2016). Export strategic orientationperformance relationship: Examination of its enabling and disenabling boundary conditions, Journal of Business Research, 69:5046-5052.

Carrasco, G., Angeles, A. \& Marroquin-Tovar, E. (2016). Inflexibility in organizational decision-making, Journal of Business Economics and Management, 17(4), 564-579.

Centeno, E., Hart, S. \& Dinnie, K., (2013). The five stages of SME brand-building, Journal of Brand Management, 20(6), 445-457.

Danese, P., Romano, P., \& Formentini, M. (2013). The Impact of Supply Chain Integration on Responsiveness: The Moderating Effect of using an International Supplier Network, Transportation Research Part E, Logistics and Transportation Review, 49 (1), 125-140.

Das, S., Dash, M., Sahoo, K., \& Mishra, U.S. (2018). Study on effectiveness of celebrity endorsements in print \& social media advertisements on the buying behavior of consumers, Review Escapade, 44: 39-28.

De Waard, E. J., Volberda, H. W., \& Soeters, J. (2012). How to support sensing capabilities in highly volatile situations, Journal of Management and Organization, 18(6), 774-794

Devinney, T. M., Auger, P., \& Eckhardt, G. M. (2010). The Myth of the Ethical Consumer. UK: Cambridge Press.

Dong, X., Hinsch, C.A., Zou, S, \& Fu, H. (2013). The effect of market orientation dimensions on multinational SBU's strategic performance, International Market Review, 30(6),591-616.

Dunne, P., Lusch, R., \& Carver, J. (2010). Retailing, (7th ed.). Boston, MA: Cengage Learning.

Ekweozor, C. U. \& Obara, C. E. (2020). Worker competence development and organizational responsiveness of selected deposit money banks in Rivers State, Nigeria, International Journal of Innovative Social Sciences $\mathcal{E}$ Humanities Research, $8(1), 12-19$.

Etemad, H. (2015). The promise of a potential theoretical framework in international entrepreneurship: An entrepreneurial orientation-performance relation in internationalized context, Journal of International Entrepreneurship, 13:89-95. 
Faron, A. (2012). Relations between lean management and organizational structures. Research in Logistics and Production. 2, (1), 103 - 114.

Farooq, S., \& O'Brien, C. (2015). An Action Research Methodology for Manufacturing Technology Selection: A Supply Chain Perspective. Production Planning \& Control The Management of Operations, 26 (6), 467-488.

Fransen, L. (2012). Corporate Social Responsibility and Global Labor Standards: Firms and Activists in the Making of Private Regulation. New York: Routledge.

Gnizy, I., Baker, W. E., \& Grinstein, A. (2014). Proactive learning culture: a dynamic capability and key success factor for SMEs entering foreign markets, International Market Review, 31(5), 477-505.

Goromonzi, W. O. (2016). Organizational culture, strategy implementation and commercial bank performance in Zimbabwe, International Review of Management and Marketing, 6(2), 307-316.

Hao, Q., Kasper, H. \& Muehlbacher, J. (2012). How does organizational structure influence performance through learning and innovation in Austria and China, Chinese Management Studies, 6(1), 36-52.

Helm, R., Krinner, S., \& Schmalfuß, M. (2014). Conceptualization and integration of marketing intelligence: The case of an industrial manufacturer, Journal of Businessto-Business Marketing, 21: 237-255.

Helo, S. (2013). The Role of the Marketing Information System in Strategic Marketing Planning - Applied Research in Rafidain Bank (Head Office), Institute of Management, 4(2), 2-12.

Huo, B. (2014). The impact of supply chain integration on firm performance: The moderating role of competitive strategy. Supply Chain Management, $A n$ International Journal, 19(4), 1- 14.

Ifinedo, P. (2013). Information systems security policy compliance: An empirical study of the effects of socialization, influence, and cognition, Information $\mathcal{E}$ Management, 06(03), 46-58.

Ismail, W. K. W., Darestani, H., \& Irani, M. A. (2011). Quality excellence model: A review of researches in Developing countries, International Journal of Fundamental Psychology and Social Sciences, 1(2), 35-41.

Kandemir, D., \& Acur, N. (2012). Examining proactive strategic decision-making flexibility in new product development, Journal of Product Innovation Management, 29(4), 608-622.

Khawla, W. (2013). The role of marketing information systems in enhancing competitive advantage- Case Study: LINDE GAS Foundation Ennaba Branch during 2013. Algeria: Kasdi Merbah Ouargla University.

Kim, D., Cavusgil, S. T., \& Cavusgil, E. (2013). Does IT Alignment between Supply Chain Partners Enhance Customer Value Creation, An Empirical Investigation, Industrial Marketing Management ,42 (6), 880-889.

Kumar, M., \& Charles, V. (2010). Evaluation of major factors in delivery of service quality of retail banks, Journal of Internal Reliability and Quality Management, 25 (2), 210-245. 
McDowell, W. C. (2013). The impact of organizational efficacy and flexibility on small business performance, The Coastal Business Journal, 12(1) 38-46.

Murphy, D. P. (2012). Why Agnostic Sign Restrictions Are Not Enough: Understanding the Dynamics of Oil Market VAR Models, Journal of the European Economic Association, 10 (5), 1166-1188.

Nicholas, J., Ledwith, A. \& Perks, H. (2011). New product development best practice in SME and large organisations: Theory vs practice, European Journal of Innovation Management, 14(2), 227-251.

Ozioko, E. A. (2017). Organizational agility and corporate responsiveness of telecommunication firms in Rivers State, Dissertation submitted to the Postgraduate school, Rivers State University for the award of master's degree of science (MS.C) in Management Business Policy option.

Pattison, S. \& Edgar, A. (2011). Integrity and the Moral Complexity of Professional Practice, Nursing Philosophy, 12 (2), 94-106.

Pehrsson, A. (2014). Firms' customer responsiveness and performance: the moderating roles of dyadic competition and firm's age, Journal of Business and Industrial Marketing, 29(1), $34-44$.

Pehrsson, A. (2016). Firm's strategic orientation, market context, and performance: literature review and opportunities for international strategy research, European Business Review, 28(4), 378-404.

Pehrsson, A. (2019). When are innovativeness and responsiveness effective in a foreign market, Journal of International Entrepreneurship, 17(14), 19-40.

Pehrsson, T., Ghannad, N., Pehrsson, A., Abt, T., Chen, S. \& Hammarstig, T. (2015). Dynamic capabilities and performance in foreign markets: Developments within international new ventures, Journal of International Entrepreneurship, 13(1),28-48.

Pogrebnyakov, N., \& Maitland, C. F. (2011). Institutional distance and the internationalization process: the case of mobile operators, Journal of International Management, 17:68-82.

Rahma, I. (2015). The role of marketing intelligence in developing the services of the Palestinian banking sector. Ph. D thesis submitted to Suez Canal University. Egypt.

Shariff, S. N. F., Omar, M. B., Sulong, S. N. B., Majid, H. A. B., Ibrahim, H. B. M., Jaafar, Z. B., \& Ideris, M. S. K. (2017). The influence of service quality and food quality towards customer fulfillment and revisit intention, Canadian Social Science, 11(8), 138-144.

Shariq, M. \& Tondon R. (2012). A study of ATM usage in Banks in Lucknow, Kanpur \&Varansi. International Journal of Engineering \& Management Sciences, 3: 34- 40.

Sparks, B. A., \& Weber, K. (2012). The service encounters. In P. Jones \& A. Pizam (Eds.) Handbook of hospitality operations and IT. Oxford, United Kingdom: Butterworth Heinemann.

Teece, D. J., (2016). Dynamic capabilities and entrepreneurial management in large organizations: Toward a theory of the (entrepreneurial) firm, European Economic Review, 86: 202-216. 
Umelue, O. G., \& Akwaeze, A. E. (2019). Task environment and organisational responsiveness in Nigerian Banks, International Journal of Trend in Scientific Research and Development, 3 (4), 456-464.

Venter, P., \& Van Rensburg, M. J. (2014). The relationship between marketing intelligence and Market orientation, Strategic Marketing Journal, 17(4), 440-4470.

Wafy, W. (2013). The Awareness and Practice of Small and Medium Size Businesses in Gaza Strip to Competitive Intelligence Concept and Its Benefits Construction and Information Technology Sector. Gaza, Palestine: Islamic university.

Wan, W., Hoskisson, R., Short, J., \& Yiu, D. (2011). Resource-based theory and corporate diversification: accomplishments and opportunities, Journal of Management, 37(5), 1335-1368. 
Georgewill, Ibiba Ambie

STRUCTURAL FLEXIBILITY AND CORPORATE RESPONSIVENESS

IN THE BUSINESS ENVIRONMENT: A THEORETICAL REVIEW

Creative Commons licensing terms

Authors will retain copyright to their published articles agreeing that a Creative Commons Attribution 4.0 International License (CC BY 4.0) terms will be applied to their work. Under the terms of this license, no permission is required from the author(s) or publisher for members of the community to copy, distribute, transmit or adapt the article content, providing a proper, prominent and unambiguous attribution to the authors in a manner that makes clear that the materials are being reused under permission of a Creative Commons License. Views, opinions and conclusions expressed in this research article are views, opinions and conclusions of the author(s). Open Access Publishing Group and European Journal of Economic and Financial Research shall not be responsible or answerable for any loss, damage or liability caused in relation to/arising out of conflict of interests, copyright violations and inappropriate or inaccurate use of any kind content related or integrated on the research work. All the published works are meeting the Open Access Publishing requirements and can be freely accessed, shared, modified, distributed and used in educational, commercial and non-commercial purposes under a Creative Commons Attribution 4.0 International License (CC BY 4.0). 